\title{
STUDI EFEK SAMPING OBAT PADA PASIEN NEONATUS YANG MENJALANI RAWAT INAP DI RUMAH SAKIT ANGKATAN LAUT DR. RAMELAN SURABAYA
}

\author{
Victoria Yulita Fitriani $^{1)}$, Widyati $^{2)}$, Azis Huibeis ${ }^{3)}$, Retno Wisanti ${ }^{2)}$ \\ Kelompok Bidang Ilmu Farmakologi-Farmasi Klinik, Fakultas Farmasi, \\ Universitas Mulawarman, Samarinda \\ e-mail :vloved29@gmail.com ${ }^{1)}$ \\ Rumah Sakit Angkatan Laut Dr. Ramelan, Kota Surabaya ${ }^{2)}$ \\ Fakultas Farmasi Universitas Surabaya, Kota Surabaya ${ }^{3)}$
}

\begin{abstract}
Rational drug treatments to avoid adverse drug reactions in neonates are depend on physiologic immaturity and age-related changes in pharmacokinetic and pharmacodynamic factor. This condition lead neonates more prone to adverse drug reaction than adults.The aim of this study was to estimate the prevalence of adverse drug reactions that occured at Dr. Ramelan Navy Hospital's NICU observed in November $26^{\text {th }} 2007$ to January $26^{\text {th }} 2008$. It was also to analyze kind of medication that caused adverse drug reactions. The study employed 94 patients (5 premature neonates and 89 term neonates) who were observed perspectively from November $26^{\text {th }} 2007$ to January $26^{\text {th }}$ 2008. Demographic data, drug therapy, relevant medical histories, laboratory data were recorded in this study. The study result was assessed by literature study. The study result were analysed with Descriptive analysis. The most common adverse drug reaction occurred in this population was potential adverse drug reaction (99.5\%). The most adverse drug reaction generated from this study was come from the use of ampicillin sulbactam (42.7\%), gentamisin (31.4\%), ceftriaxone $(16.2 \%)$, amikacin $(7.6 \%)$, aminofilin (1.1\%), ampicillin (0.5\%), and dexamethasone $(0.5 \%)$. The study showed that almost all of adverse drug reaction occurred in this study was potential adverse drug reaction (99.5\%).
\end{abstract}

Keywords: neonates; adverse drug reactions; NICU

\begin{abstract}
ABSTRAK
Terapi obat yang rasional untuk menghindari efek samping dari obat pada neonatus bergantung pada ketidakmatangan fisiologik dan perubahan faktor farmakokinetika dan farmakodinamika yang terkait usia. Kondisi ini membawa neonatus lebih mudah terpapar efek samping obat daripada orang dewasa. Tujuan dari penelitian ini adalah untuk memperkirakan angka kejadian efek samping obat yang terjadi di NICU Rumah Sakit Angkatan Laut Dr. Ramelan Surabaya diamati secara prospektif sejak 26 November 2007 hingga 26 Januari 2008. Penelitian ini juga menganalisa jenis obat yang menyebabkan efek samping obat. Penelitian ini melibatkan 94 pasien ( 5 neonatus premature dan 89 neonatus term) yang diamati secara prospektif sejak 26 November 2007 hingga 26 Januari 2008. Penelitian ini mencatat data demografi, terapi obat, sejarah penyakit yang terkait, dan data laboratorium. Data tersebut dianalisa melalui studi literatur. Hasil penelitian dianalisa dengan menggunakan analisis
\end{abstract}


Studi efek samping obat pada pasien neonatus yang menjalani rawat inap di rumah sakit angkatan laut dr. Ramelan Surabaya

deskriptif. Efek samping obat yang sering muncul pada penelitian ini adalah efek samping potensial (99.5\%). Efek samping yang terjadi pada penelitian ini terjadi akibat penggunaan ampisilin sulbaktam (42.7\%), gentamisin (31.4\%), ceftriaxon $(16.2 \%)$, amikasin $(7.6 \%)$, aminofilin $(1.1 \%)$, ampisilin $(0.5 \%)$, dan deksametason $(0.5 \%)$. Penelitian ini menunjukkan bahwa sebagian besar efek samping obat yang terjadi pada penelitian ini adalah efek samping obat potensial.

Kata kunci: neonatus; efek samping obat; NICU

\section{PENDAHULUAN}

Masa kanak-kanak menggambarkan suatu periode pertumbuhan dan perkembangan yang cepat. Penggunaan obat untuk anakanak merupakan hal khusus yang berkaitan dengan perbedaan laju perkembangan organ, sistem dalam tubuh maupun enzim yang bertanggung jawab terhadap metabolisme dan ekskresi obat. Sesuai dengan alasan tersebut maka dosis obat, formulasi, hasil pengobatan dan efek samping obat yang timbul sangat beragam sepanjang masa anak-anak. Pemakaian obat untuk anak-anak belum diteliti secara luas, sehingga hanya terdapat sejumlah kecil obat yang telah diberi ijin untuk digunakan pada anak-anak, yang memiliki bentuk sediaan yang sesuai. ${ }^{2}$ Terapi obat yang aman dan efektif untuk anak membutuhkan pemahaman mengenai variasi yang luas dan perubahan konstan dalam hal penanganan farmakokinetik dan respon farmakodinamik terhadap obat yang terjadi selama waktu mulai lahir sampai dewasa. ${ }^{3}$ Walaupun diberikan pada dosis yang paling tepat, pengobatan obat pada anak dapat menyebabkan perbedaan dalam hal keefektifan dan efek samping obat dibandingkan penggunaannya pada pasien dewasa. ${ }^{8}$ Pasien pediatrik dibagi menjadi ${ }^{9}$ kelompok yaitu premature infants, full term infants, neonatus, infants, children, adolescents. ${ }^{10} \quad$ Neonatus didefinisikan sebagai bayi yang berusia kurang dari 28 hari. ${ }^{4}$ Dibandingkan dengan pasien yang lebih tua, pasien neonatus mengalami perbedaan dalam absorpsi, distribusi, metabolisme dan eliminasi obat. Hal tersebut dapat memiliki efek yang menyeluruh terhadap hasil terapi. Dalam populasi neonatus, perbedaan selanjutnya muncul antar kelompok, contohnya pasien yang lahir saat usia kandungan atau berat badan tertentu. ${ }^{9}$ Berdasarkan pemikiran diatas dapat terlihat bahwa neonatus berada dalam posisi yang rentan mengalami efek samping obat. Hal ini mendorong untuk dilakukannya studi mengenai efek samping obat yang terjadi pada pasien neonatus.

\section{METODE}

Pada penelitian yang dilakukan sejak 26 November 2007 - 26 Januari 2008, 94 pasien ( 5 pasien neonatus prematur dan 89 pasien neonatus term) diikut sertakan dalam penelitian prospektif observasional ini. Pasien yang diamati merupakan pasien yang mengalami rawat inap di NICU (Neonatal Intensive Care Unit). Data demografis, obat-obat yang digunakan, sejarah kesehatan yang relevan, data laboratorium, kondisi kesehatan dicatat secara prospektif. Sejumlah buku dan pedoman terapi digunakan sebagai acuan untuk mengidentifikasi efek samping obat yang terjadi, baik yang bersifat aktual maupun potensial.

\section{HASIL DAN PEMBAHASAN}

Populasi penelitian ini mengalami 185 kejadian efek samping. Kejadian efek samping yang bersifat aktual hanya terjadi 1 kejadian yaitu akibat penggunaan 
Studi efek samping obat pada pasien neonatus yang menjalani rawat inap di rumah sakit angkatan laut dr. Ramelan Surabaya

ampisilin/sulbaktam yang menyebabkan terjadi rash pada kulit. Efek samping ini terjadi pada neonatus term. 184 kejadian efek samping lainnya yang terjadi pada neonatus (15 kejadian pada neonatus prematur dan 169 kejadian pada neonatus term) hanya bersifat potensial.

Tujuan penelitian ini adalah mengidentifikasi dan mengetahui kejadian efek samping yang paling sering terjadi pada pasien neonatus yang menjalani rawat inap di NICU (neonatal intensive care unit) Rumah Sakit Angkatan Laut Dr. Ramelan. Neonatus yang menjalani rawat inap sebagian besar dikarenakan neonatus tersebut memiliki risiko tinggi terhadap terjadinya infeksi yang ditandai salah satunya dengan ketuban berwarna hijau keruh / keruh dan / atau KPP > 12 jam.

Pemeriksaan laboratorium yang standar dilakukan pada pasien neonatus adalah darah lengkap dimana yang diperiksa adalah leukosit, trombosit, $\mathrm{Hb}$, dan differential count. Mengidentifikasi dan mengawasi kemungkinan terjadinya efek samping obat merupakan salah satu tanggung jawab farmasis dalam menjalankan pharmaceutical care pada neonatus.

Identifikasi efek samping obat dapat ditemukan dari hasil review terhadap peresepan. ${ }^{9}$ Efek samping potensial $(69,2$ $\%)$ paling sering terjadi pada pasien neonatus, pada neonatus prematur terjadi sebesar 5,6\% dan neonatus term $63,5 \%$.

Efek samping potensial tersebut antara lain disebabkan oleh pemakaian obat ampisilin sulbaktam, gentamisin, ceftriaxon, amikasin, aminofilin dan dexametason. Efek samping potensial yang paling dikhawatirkan adalah efek nefrotoksik dari pemakaian gentamisin $(29,9 \%)$ dan amikasin $(6 \%)$ yang tereliminasi lewat ginjal.

Elinasi dan t1/2 pada neonatus secara umum mengalami penurunan sehingga obat akan lebih lama tinggal di dalam tubuh dan risiko nefrotoksik meningkat.

Tabel 1. Frekuensi Efek Samping

\begin{tabular}{|c|c|c|c|c|c|c|c|c|}
\hline \multirow{2}{*}{$\begin{array}{c}\text { Jenis efek } \\
\text { samping }\end{array}$} & \multicolumn{2}{|c|}{ Frekuensi } & \multirow{2}{*}{$\begin{array}{l}\text { Total } \\
\mathrm{N}(\%)\end{array}$} & \multirow[t]{2}{*}{ Obat Penyebab } & \multicolumn{2}{|c|}{ Frekuensi } & \multirow{2}{*}{$\begin{array}{l}\text { Frek. } \\
\text { N (\%) }\end{array}$} & \multirow{2}{*}{$\begin{array}{l}\% * \\
(\%)\end{array}$} \\
\hline & $\begin{array}{c}\text { Prematur } \\
\mathrm{N}(\%)\end{array}$ & $\begin{array}{l}\text { Term } \\
\mathrm{N}(\%)\end{array}$ & & & $\begin{array}{c}\text { Prematur } \\
\mathrm{N}(\%)\end{array}$ & $\begin{array}{c}\text { Term } \\
\mathrm{N}(\%)\end{array}$ & & \\
\hline Aktual & & $1(0.5)$ & $1(0.5)$ & $\begin{array}{l}\text { Ampisilin } \\
\text { Sulbaktam }\end{array}$ & & $\begin{array}{l}1 \\
(100)\end{array}$ & $1(100)$ & 0.5 \\
\hline \multirow[t]{7}{*}{ Potensial } & $15(8.1)$ & $\begin{array}{l}169 \\
(91.4)\end{array}$ & $184(99.5)$ & Amikasin & $3(1.6)$ & $\begin{array}{l}11 \\
(6.0)\end{array}$ & $\begin{array}{l}14 \\
(7.6)\end{array}$ & 7.6 \\
\hline & & & & Aminofilin & $1(0.5)$ & $1(0.5)$ & $2(1)$ & 1.1 \\
\hline & & & & Ampisilin & & $1(0.5)$ & $1(0.5)$ & 0.5 \\
\hline & & & & $\begin{array}{l}\text { Ampisilin } \\
\text { Sulbaktam }\end{array}$ & $5(2.7)$ & $\begin{array}{l}73 \\
(39.7)\end{array}$ & $\begin{array}{l}78 \\
(42.4)\end{array}$ & 42.2 \\
\hline & & & & Ceftriaxone & $3(1.6)$ & $\begin{array}{l}27 \\
(14.7)\end{array}$ & $\begin{array}{l}30 \\
(16.3)\end{array}$ & 16.2 \\
\hline & & & & Dexametason & & $1(0.5)$ & $1(0.5)$ & 0.5 \\
\hline & & & & Gentamisin & $3(1.6)$ & $\begin{array}{l}55 \\
(29.9)\end{array}$ & $\begin{array}{l}58 \\
(31.5)\end{array}$ & 31.4 \\
\hline Total & $15(8.1)$ & $\begin{array}{l}170 \\
(91.9)\end{array}$ & $185(100)$ & & & & & 100 \\
\hline
\end{tabular}


Studi efek samping obat pada pasien neonatus yang menjalani rawat inap di rumah sakit angkatan laut dr. Ramelan Surabaya

Eliminasi obat yang melibatkan filtrasi glomerular, sekresi tubular dan reabsorpsi tubulur mengalami penurunan pada neonatus prematur, sedangkan nilai filtrasi glomerular pada neonatus term saat lahir 2 kali lebih besar dalam 2 minggu pertama, hal ini menyebabkan neonatus prematur memiliki risiko nefrotoksik yang lebih besar terhadap pemakaian gentamisin dan amikasin. $^{15}$

Namun pada penelitian ini, tidak ada efek nefrotoksik yang terjadi baik pada neonatus prematur dan term. Efek nefrotoksik ini tidak dapat dibuktikan kejadiannya karena tidak dilakukan pemeriksaan fungsi ginjal rutin pada setiap bayi yang menjalani rawat inap.

Seharusnya hal ini dilakukan mengingat obat yang digunakan berpotensi nefrotoksik. Jika golongan aminoglikosida digunakan sebagai terapi pilihan maka disarankan untuk mencukupi kebutuhan cairan pasien dan menghindari penggunaan bahan / obat lain yang nefrotoksik, sehingga dapat mencegah gagal ginjal akut yang dipicu oleh amoniglikosida. Efek nefrotoksik yang ditimbulkannya bersifat reversibel. $^{7}$

Efek samping lain dari golongan aminoglikosida yang juga dianggap penting adalah efek ototoksik, yang pada penelitian ini juga tidak dapat dibuktikan kejadiannya karena tidak dilakukan test pendengaran pada neonatus.

Namun pada penelitian prospektif mengenai prevalensi gangguan pendengaran pada populasi di neonatal intensive care unit ( 942 pasien neonatus diamati), pemberian aminoglikosida tidak menjadi faktor risiko yang penting dalam terjadinya gangguan pendengaran terkait komunikasi.
Pada sebagian besar kasus lebih banyak disebabkan oleh faktor lain (dysmorphism, prenatal rubella atau cytomegaly, a positie family history of hearing loss, and severe perinatal and postnatal complications). ${ }^{1}$

Efek samping potensial yang lain muncul dari risiko reaksi hipersensitivitas obat akibat pemakaian ampisilin sulbaktam $(42,4 \%)$ dan ceftriaxon $(14,7 \%)$.

Namun reaksi hipersensitivitas ini hanya terjadi pada 1 pasien neonatus term dengan manifestasi rash akibat pemakaian ampisilin sulbaktam (efek samping aktual $0,4 \%$ ). Persentase kejadian rash pada ampisilin sulbaktam secara umum berkisar $1-10 \%$ dan pada ceftriaxon $2 \% .^{11}$

Faktor-faktor yang mempengaruhi terjadinya reaksi hipersensitivitas adalah dosis obat, rute pemberian obat, durasi obat dan terdapat juga faktor genetik yang mempengaruhi metabolisme dan eksresi obat. Faktor genetik ini memodulasi risiko dan tingkat keparahan dari rekasi hipersensitivitas, sehingga reaksi hipersensitivitas ini tidak terjadi pada setiap orang. ${ }^{1}$

Aminofilin memiliki rentang terapi yang sempit sehingga terdapat penimgkatan risiko efek samping potensial berupa toksisitas pada neonatus dimana proses biotransformasinya mengalami penurunan sehingga terdapat potensi akumulasi obat dan efek farmakologis yang berlebihan, selain itu eliminasi obat ini juga mengalami penurunan sehingga obat tinggal lebih lama dalam tubuh. ${ }^{15}$

Efek ini tidak terjadi secara klinis baik pada neonatus prematur maupun term. Hal ini diduga dikarenakan dosis yang diberikan pada neonatus di penelitian ini telah disesuaikan dengan usia dan berat 
Studi efek samping obat pada pasien neonatus yang menjalani rawat inap di rumah sakit angkatan laut dr. Ramelan Surabaya

badan serta masuk rentang terapi yaitu 4 - 6 $\mathrm{mg} / \mathrm{kgBB} /$ hari. $^{11}{ }^{12}$

Neonatus pada penelitian ini tidak menjalani therapeutic drug monitoring dikarenakan masalah biaya dan kesulitan dalam mengambil sampel darah pada bayi, namun hal yang perlu diperhatikan adalah terdapat variasi individu terhadap kadar terapetik maupun toksisitas aminofilin (terbukti pada pasien dewasa). Penggunaan dexametason pada neonatus dapat meningkatkan risiko keparahan infeksi. ${ }^{14}$

Risiko ini timbul akibat efek samping dari dexametason yang menekan sistem imun pasien. Peningkatan risiko infeksi akibat pemakaian dexametason ini tidak terbukti melalui seuatu penelitian yang mengamati pemakaian dexametason lebih dari 9 minggu pada neonatus preterm yang menjalani rawat inap di NICU (Neonatal Intensive Care Unit), dimana penelitian ini menunjukkan tidak ada perbedaan yang ditemukan daalm kejadian sepsis atau pola sepsis atau secara bakteriologi lain yang dapat membuktikan infeksi. ${ }^{13}$

Kesulitan yang ditimbulkan dalam penilaian terjadinya efek samping adalah ketidakmampuan neonatus untuk menyampaikan efek yang dirasakannya saat mendapat obat tersebut. Hal ini otomatis menimbulkan kesulitan pengamatan pada obat-obat yang menyebabkan efek-efek samping yang membutuhkan pengamatan klinis seperti mual, muntah, diare.

Muntah pada neonatus tidak hanya disebabkan oleh obat namun juga dapat disebakan oleh alergi makanan, penebab yang paling sering adalah intolerance terhadap protein susu sapi, hal ini terjadi pada sebagian besar bayi yang mengkonsumsi susu formula. ${ }^{17}$
Diare pada neonatus dapat disebabkan oleh alergi makanan/susu, efek samping fototerapi pada neonatus yang mendapat perlakuan fototerapi, gejala sepsis dan efek samping dari obat. ${ }^{5,6,16}$

Oleh karena itu, untuk memastikan apakah gejala klinis yang dialami oleh neonatus tersebut merupakan efek samping obat atau tidak, perlu dilihat waktu mulai pemberian obat dihubungkan dengan waktu gejala tersebut muncul, frekuensi mual/muntah atau diare, dan faktor-faktor lain yang dapat menimbulkan gejala tersebut.

\section{KESIMPULAN}

Kejadian efek samping yang terjadi pada penelitian ini sebagian besar merupakan efek samping potensial (184 kejadian).

\section{DAFTAR PUSTAKA}

1. Aronson, J.K. 2006, Meyler's Side Effects of Drugs, Fifteenth Edition, Elsevier; Amsterdam, 122, 140-145, 1506

2. Aslam, M.; Tan, C.K.; \& Prayitno, A. 2003, Farmasi Klinis (Clinical Pharmacy), Elex Media Komputindo; Jakarta, 10-12, 50-70

3. Conroy, S. 2003, Paediatric Pharmacy-drug Therapy, Hospital Pharmacy Vol.10 (February): 1-4

4. El-chaar, G. 2003, Pharmaceutical care of Premature Infants, US Pharmacists (December). Available from : http://www.uspharmacist.com/index.asp?show $=$ article\&page $=8 \_1650 . \mathrm{htm}$ [cited May 16 2007]

5. Gilmore, M.M.; Uy, C.C. 2004, Hyperbilirubinemia, In : Neonatalogy Management, Procedures, On-Call Problems, Disease, And Drugs, Fifth Edition, McGrawHill Companies, Inc.; United States, 25-31

6. Harianto, A. 2006, Sepsis neonatorum, In : Pedoman Diagnosis \& Terapi Divisi Neonatalogy, Edisi 3, Bag./SMF Ilmu Kesehatan Anak FK UNAIR/RSU Dr. Soetomo; Surabaya, 6-10

7. Howell, H.R.; Brundige, M.S; \& Langworthy, L. 2007, Drug Induced Acute Renal Failure, US Pharm 32(3):45-50. 
Studi efek samping obat pada pasien neonatus yang menjalani rawat inap di rumah sakit angkatan laut dr. Ramelan Surabaya

8. Keady, S.; Costello, I.; \& Tomlin, A, 2005, A career as specialist paediatric pharmacists. Hospital Pharmacists Vol.25. (January) : $1-4$

9. Khoo, G.P.; \& Bolton, O. 2003, Neonatal dan paediatric intensive care, Hospital Pharmacists Vol.10: 1-4

10. Koda-Kimble, M.A.; Young, L.Y.; Kradjan, W.A.; Guglielmo, B.J.; Alldredge, B.K.; \& Corelli, R.L. 2005, Applied Therapeutics - The Clinical Use of Drugs, Eight edition, Lippincott-Williams \& Wilkins; London, 62-64

11. Lacy, C.F.; Armstrong, L.L.; Goldman, M.P.; Lance, L.L. 2006, Drug information Handbook, $14^{\text {th }}$ Edition, Lexi-Comp; Ohio, 28, 86, 118, $300,731,772$

12. Martin, J.; Mehta, D.K.; Jordan, B.; Macfarlane, C.R.; Ryan, R.S.M.; \& Wagle, S.M.S. 2007, BNF for Children, BMJ Publishing Group Ltd; London, 326, 306, 316, 437, 325, 175.
13. Ng, P.C.; Thomson, M.A.; \& Dear, P.R. 1990, Dexamethasone and Infection in Preterm Babies : a controlled study, Archives of Disease in Childhood 65: 54-56

14. Orlando Regional Healthcare, Education \& Development. 2004, Neonatal Sepsis, 1-16

15. Reiter, P.D. 2002, Neonatal Pharmacology and Pharmacokinetics, NeoReviews Vol.3 No.11 (November): 1-7

16. Sondheimer, J.M. 2007, Gastrointestinal Tract, In : Current Pediatric Diagnosis \& Treatment, $18^{\text {th }}$ Edition, The McGraw-Hill; United States of America, p. 52

17. Withers, G.; \& Scott, R.B. 2002, Vomiting and Regurgitation, In : First Principles Gastroenterology Chapter 15 Pediatrics, (Online), Available from : http://www.gastroresource.com/GITextbook/En /Chapter15/15-2.htm [cited March 1 2008] 